\title{
Do Impact Fees Pay For The Infrastructure Costs Required By New Developments?
}

Antonio Apap, University of West Florida

Dana L. Cicheskie, Science Applications International Corporation

\begin{abstract}
This study investigated impact fees used by counties and communities to pay for infracture costs required by development and found that the impact fees do not pay the full costs of the infrastructure required by the new development. The major impact fees are for roads and schools, however, impact fees are also routinely used for fire protection, police protection, emergency services, correctional facilities, parks, libraries, government buildings and drainage. Florida was used as a proxy for the 34 states that use impact fees. Since roads and schools cause the highest burden on the communities experiencing growth, comparisons of cost vs. impact fee revenues were limited to roads and schools.
\end{abstract}

Keywords: State impact fees, Florida County impact fees, residential impact fees, infrastructure costs

\section{INTRODUCTION}

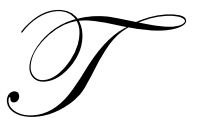

he purpose of this research was to determine if impact fees pay for the infrastructure costs required by new single-family developments. Impact fees are used by counties, municipalities, special districts, and school districts to pay for the costs of additional infrastructure required as a result of new development. The major impact fees typically imposed are for roads and schools, however, impact fees are also routinely charged for fire protection, police protection, emergency medical services, correctional facilities, parks, libraries, government buildings, and drainage. Impact fees in this paper do not include water and sewer costs because in many communities these utilities are independently owned and normally charge for sewer and water taps when building permits are obtained.

Impact fees are used in 34 states in the U.S. and their use stretches across the nation from Hawaii to New Hampshire. Table 1 provides the total average impact fee for each state as well as the average impact fees for roads, drainage, parks, libraries, fire protection, police protection, government buildings, schools, and other impact fees. Other impact fees include categories of expenses such as correctional facilities and the costs required for administering the impact fee system. The total impact fees levied by the states varies widely for a three bedroom, 2,000 sf single-family home from the highest fees levied by Virginia $(\$ 38,151)$ and California $(\$ 29,740)$ to the lowest fees of Oklahoma (\$647) and Missouri (\$861). The average impact fee for the 34 states which have counties or municipalities that levy impact fees is $\$ 6,701$ for a three bedroom, 2,000 sf single-family home. School impact fees, although not levied in some states, are the highest category of impact fee $(\$ 5,076)$.

A literature review revealed some important results concerning impact fees. Moon (2006), in his study on Florida impact fee adoptions, found that rapid growth promotes impact fee adoptions, and that counties are more prone to adopting impact fees when neighboring counties have adopted them. Concerning the effect impact fees have on existing homeowners, Yinger (1998) found that impact fees result in a small capital gain on existing homeowners and do not adversely affect developers. Furthermore, Ihlanfeldt and Shaughnessy (2004) found that impact fees reduce millage rates, and the present value of property tax savings are about equal to the effects of impact fees on housing prices. One of the objections often used to sway opinions against impact fees is the theory that impact fees make low cost housing unaffordable. Concerning the effects of impact fees on multi-family housing construction in Florida, Burge and Ihlanfeldt (2006) found that nonwater/sewer impact fees cause an increase in the 
construction of multi-family housing within inner suburban areas because nonwater/sewer impact fees reduce the developer's cost of obtaining project approval enough to offset the cost of the impact fees.

Table 1

Single-Family Unit (3BR, 2,000 sf on 10,000 sf Lot)

\begin{tabular}{|c|c|c|c|c|c|c|c|c|c|c|}
\hline State & Roads & Drainage & Parks & Libraries & Fire & Police & $\begin{array}{c}\text { Gov } \\
\text { Bldg }\end{array}$ & Schools & Other & Total \\
\hline Arkansas & $\$ 1,039$ & $\mathrm{n} / \mathrm{a}$ & $\$ 659$ & $\mathrm{n} / \mathrm{a}$ & $\$ 472$ & $\$ 162$ & $\mathrm{n} / \mathrm{a}$ & $\mathrm{n} / \mathrm{a}$ & $\mathrm{n} / \mathrm{a}$ & $\$ 2,332$ \\
\hline Arizona & 2,193 & 563 & 1,994 & 385 & 464 & 387 & 544 & $\mathrm{n} / \mathrm{a}$ & 612 & 7,142 \\
\hline California & 5,267 & 2,003 & 7,890 & 685 & 768 & 895 & 2,775 & 4,907 & 4,460 & 29,740 \\
\hline Colorado & 2,218 & 1,114 & 3,252 & 605 & 336 & 276 & 417 & 1,142 & 582 & 9,942 \\
\hline Delaware & $\mathrm{n} / \mathrm{a}$ & $\mathrm{n} / \mathrm{a}$ & 328 & 138 & 517 & 62 & 112 & $\mathrm{n} / \mathrm{a}$ & $\mathrm{n} / \mathrm{a}$ & 1,157 \\
\hline Florida & 3,395 & 97 & 1,103 & 206 & 319 & 255 & 430 & 4,574 & 268 & 10,647 \\
\hline Georgia & 869 & $\mathrm{n} / \mathrm{a}$ & 713 & 164 & 333 & 153 & 54 & $\mathrm{n} / \mathrm{a}$ & 11 & 2,297 \\
\hline Hawaii & 1,836 & $\mathrm{n} / \mathrm{a}$ & $\mathrm{n} / \mathrm{a}$ & $\mathrm{n} / \mathrm{a}$ & $\mathrm{n} / \mathrm{a}$ & $\mathrm{n} / \mathrm{a}$ & $\mathrm{n} / \mathrm{a}$ & $\mathrm{n} / \mathrm{a}$ & $\mathrm{n} / \mathrm{a}$ & 1,836 \\
\hline Idaho & 1,721 & $\mathrm{n} / \mathrm{a}$ & 1,503 & $\mathrm{n} / \mathrm{a}$ & $\mathrm{n} / \mathrm{a}$ & 88 & $\mathrm{n} / \mathrm{a}$ & $\mathrm{n} / \mathrm{a}$ & 28 & 3,340 \\
\hline Illinois & 658 & $\mathrm{n} / \mathrm{a}$ & 1,232 & 100 & 500 & 400 & 1,050 & 2,229 & 75 & 6,244 \\
\hline Indiana & 1,630 & $\mathrm{n} / \mathrm{a}$ & 1,176 & $\mathrm{n} / \mathrm{a}$ & $\mathrm{n} / \mathrm{a}$ & $\mathrm{n} / \mathrm{a}$ & $\mathrm{n} / \mathrm{a}$ & $\mathrm{n} / \mathrm{a}$ & $\mathrm{n} / \mathrm{a}$ & 2,806 \\
\hline Kansas & 2,401 & 905 & 465 & $\mathrm{n} / \mathrm{a}$ & $\mathrm{n} / \mathrm{a}$ & $\mathrm{n} / \mathrm{a}$ & $\mathrm{n} / \mathrm{a}$ & $\mathrm{n} / \mathrm{a}$ & $\mathrm{n} / \mathrm{a}$ & 3,771 \\
\hline Louisiana & 834 & 1,609 & $\mathrm{n} / \mathrm{a}$ & $\mathrm{n} / \mathrm{a}$ & $\mathrm{n} / \mathrm{a}$ & $\mathrm{n} / \mathrm{a}$ & $\mathrm{n} / \mathrm{a}$ & $\mathrm{n} / \mathrm{a}$ & $\mathrm{n} / \mathrm{a}$ & 2,443 \\
\hline Maryland & 2,120 & $\mathrm{n} / \mathrm{a}$ & 885 & 823 & 1,166 & 125 & $\mathrm{n} / \mathrm{a}$ & 7,462 & 350 & 12,931 \\
\hline Missouri & 861 & $\mathrm{n} / \mathrm{a}$ & $\mathrm{n} / \mathrm{a}$ & $\mathrm{n} / \mathrm{a}$ & $\mathrm{n} / \mathrm{a}$ & $\mathrm{n} / \mathrm{a}$ & $\mathrm{n} / \mathrm{a}$ & $\mathrm{n} / \mathrm{a}$ & $\mathrm{n} / \mathrm{a}$ & 861 \\
\hline Montana & 1,094 & $\mathrm{n} / \mathrm{a}$ & $\mathrm{n} / \mathrm{a}$ & $\mathrm{n} / \mathrm{a}$ & 190 & $\mathrm{n} / \mathrm{a}$ & $\mathrm{n} / \mathrm{a}$ & $\mathrm{n} / \mathrm{a}$ & $\mathrm{n} / \mathrm{a}$ & 1,284 \\
\hline N Carolina & 822 & $\mathrm{n} / \mathrm{a}$ & 420 & $\mathrm{n} / \mathrm{a}$ & $\mathrm{n} / \mathrm{a}$ & $\mathrm{n} / \mathrm{a}$ & $\mathrm{n} / \mathrm{a}$ & 2,653 & $\mathrm{n} / \mathrm{a}$ & 3,895 \\
\hline Nebraska & 2,466 & $\mathrm{n} / \mathrm{a}$ & 334 & $\mathrm{n} / \mathrm{a}$ & $\mathrm{n} / \mathrm{a}$ & $\mathrm{n} / \mathrm{a}$ & $\mathrm{n} / \mathrm{a}$ & $\mathrm{n} / \mathrm{a}$ & $\mathrm{n} / \mathrm{a}$ & 2,800 \\
\hline New Ham & 1,722 & $\mathrm{n} / \mathrm{a}$ & 840 & $\mathrm{n} / \mathrm{a}$ & 190 & $\mathrm{n} / \mathrm{a}$ & $\mathrm{n} / \mathrm{a}$ & 2,765 & $\mathrm{n} / \mathrm{a}$ & 5,517 \\
\hline New Mexico & 2,297 & 1,974 & 1,255 & $\mathrm{n} / \mathrm{a}$ & 313 & 227 & $\mathrm{n} / \mathrm{a}$ & $\mathrm{n} / \mathrm{a}$ & 60 & 6,126 \\
\hline Nevada & 1,660 & $\mathrm{n} / \mathrm{a}$ & 930 & $\mathrm{n} / \mathrm{a}$ & $\mathrm{n} / \mathrm{a}$ & $\mathrm{n} / \mathrm{a}$ & $\mathrm{n} / \mathrm{a}$ & 900 & 126 & 3,616 \\
\hline Ohio & 3,964 & $\mathrm{n} / \mathrm{a}$ & 1,125 & $\mathrm{n} / \mathrm{a}$ & 325 & 184 & 366 & $\mathrm{n} / \mathrm{a}$ & $\mathrm{n} / \mathrm{a}$ & 5,964 \\
\hline Oklahoma & 647 & $\mathrm{n} / \mathrm{a}$ & $\mathrm{n} / \mathrm{a}$ & $\mathrm{n} / \mathrm{a}$ & $\mathrm{n} / \mathrm{a}$ & $\mathrm{n} / \mathrm{a}$ & $\mathrm{n} / \mathrm{a}$ & $\mathrm{n} / \mathrm{a}$ & $\mathrm{n} / \mathrm{a}$ & 647 \\
\hline Oregon & 3,207 & 645 & 3,195 & $\mathrm{n} / \mathrm{a}$ & $\mathrm{n} / \mathrm{a}$ & $\mathrm{n} / \mathrm{a}$ & $\mathrm{n} / \mathrm{a}$ & $\mathrm{n} / \mathrm{a}$ & $\mathrm{n} / \mathrm{a}$ & 7,047 \\
\hline Pennsylvania & 2,220 & 1,610 & 1,000 & $\mathrm{n} / \mathrm{a}$ & $\mathrm{n} / \mathrm{a}$ & $\mathrm{n} / \mathrm{a}$ & $\mathrm{n} / \mathrm{a}$ & $\mathrm{n} / \mathrm{a}$ & 250 & 5,080 \\
\hline S Carolina & 887 & $\mathrm{n} / \mathrm{a}$ & 485 & 553 & 368 & 69 & $\mathrm{n} / \mathrm{a}$ & $\mathrm{n} / \mathrm{a}$ & 234 & 2,596 \\
\hline Tennessee & 1,519 & $\mathrm{n} / \mathrm{a}$ & 547 & $\mathrm{n} / \mathrm{a}$ & 378 & 282 & $\mathrm{n} / \mathrm{a}$ & 1,400 & 2,071 & 6,197 \\
\hline Texas & 1,452 & $\mathrm{n} / \mathrm{a}$ & 830 & $\mathrm{n} / \mathrm{a}$ & $\mathrm{n} / \mathrm{a}$ & $\mathrm{n} / \mathrm{a}$ & $\mathrm{n} / \mathrm{a}$ & $\mathrm{n} / \mathrm{a}$ & $\mathrm{n} / \mathrm{a}$ & 2,282 \\
\hline Utah & 1,422 & 766 & 2,422 & $\mathrm{n} / \mathrm{a}$ & 239 & 141 & $\mathrm{n} / \mathrm{a}$ & $\mathrm{n} / \mathrm{a}$ & 360 & 5,350 \\
\hline Virginia & 13,621 & $\mathrm{n} / \mathrm{a}$ & 5,049 & 626 & 807 & $\mathrm{n} / \mathrm{a}$ & 446 & 17,602 & $\mathrm{n} / \mathrm{a}$ & 38,151 \\
\hline Vermont & 329 & $\mathrm{n} / \mathrm{a}$ & 1,087 & 836 & 404 & 80 & $\mathrm{n} / \mathrm{a}$ & 6,255 & $\mathrm{n} / \mathrm{a}$ & 8,991 \\
\hline Washington & 1,394 & 856 & 1,388 & $\mathrm{n} / \mathrm{a}$ & 565 & 62 & 86 & 3,450 & $\mathrm{n} / \mathrm{a}$ & 7,801 \\
\hline W Virginia & $\mathrm{n} / \mathrm{a}$ & 751 & $\mathrm{n} / \mathrm{a}$ & $\mathrm{n} / \mathrm{a}$ & 603 & 135 & $\mathrm{n} / \mathrm{a}$ & 10,655 & $\mathrm{n} / \mathrm{a}$ & 12,144 \\
\hline Wisconsin & 94 & 785 & 2,559 & 589 & 349 & 481 & $\mathrm{n} / \mathrm{a}$ & $\mathrm{n} / \mathrm{a}$ & $\mathrm{n} / \mathrm{a}$ & 4,857 \\
\hline National Av & 2,121 & 1,052 & 1,588 & 476 & 457 & 235 & 628 & 5,076 & 678 & 6,701 \\
\hline
\end{tabular}

Source: Duncan Associates (August, 2007)

\section{METHODOLOGY}

\section{Limitations And Assumptions}

Since attempting to determine if impact fees pay for the infrastructure costs required for new single-family homes in all 34 states that charge impact fees is beyond the capability of this study, Florida was used as a proxy for all 34 states for two reasons. First, 41 out of 67 counties in Florida currently use impact fees to offset the cost of infrastructure growth related development. Second, Florida is one of the fastest growing states in the U.S. 
Water and sewer costs are not included as impact fees in this study because in many communities these utilities are independently owned and normally charge for sewer and water taps when building permits are obtained. In addition, these utilities are normally already in place when construction on new residential units begins, whereas, new schools and roads must be built to accommodate new development as it occurs.

The comparisons of cost vs. average impact fees charged will be limited to schools and roads because the costs involved with new roads and new schools are much higher than other infrastructure costs.

Finally, although impact fees are typically levied on all residential structures and on commercial buildings, this study will be limited to comparing the costs vs. the average impact fees charged to single-family, 2,000 sf homes.

\section{School Costs vs. School Impact Fees}

The methodology used by Henderson, Young \& Company (2007) to calculate the costs of educational facilities per dwelling unit in Lake County, Florida was used in this study to calculate the costs of educational facilities in Santa Rosa County, Florida. Santa Rosa County was chosen for this part of the study because the County currently does not have a school impact fee, and also because the costs involved in building a new elementary school were available. The data for constructing the new Bennett C. Russell Elementary School in Santa Rosa County follow:

- $\quad$ Construction contract, architect, and engineering fees: $\$ 19,594,637$

- $\quad$ Cost of land: land swap

- $\quad$ Cost of furniture, equipment, fixtures, and other expenses: $\$ 1,449,614$

- $\quad$ Total building cost: $\$ 21,044,251$

- $\quad$ Funding: public education capital outlay, local capital outlay taxes, $1 \frac{1}{2} \%$ sales tax, and certificates of participation.

- $\quad$ Average annual interest rate: $4.715 \%$

- $\quad$ Total expected interest paid over 25 years on $\$ 20.0$ million borrowed: $\$ 23,996,472$

- $\quad$ Present value (discount rate $2.133 \%$ ) of interest cost $=\$ 14,157,918$

- $\quad$ School busses required: none (bussing children contracted to private business)

- $\quad$ Student capacity: 900

- $\quad$ Estimated new dwelling units per year $=1,492$

- $\quad$ Estimated students per dwelling unit $=0.42$

Steps required to calculate costs of educational facilities follow:

Step 1. Calculate the cost of the facilities per student using Equation 1.

Cost per Student $=$ Cost of Educational Facilities/Student Capacity

Step 2. Calculate the cost of the educational facilities per dwelling unit using Equation 2.

Cost per Dwelling Unit $(\mathrm{DU})=$ Cost per Student $\mathrm{x}$ Students per $\mathrm{DU}$

Step 3. Calculate the estimated yearly costs for new schools per year using Equation 3.

Est. Yearly Costs for New Schools $=$ Cost per DU x Number of New DUs/Year

Step 4. Compare the estimated yearly costs for new facilities to the number of new DUs per year $\mathrm{x}$ the average Florida school impact fee. 


\section{Transportation Costs vs. Transportation Impact Fees}

The methodology used by Duncan Associates (July, 2007) to calculate the costs of transportation per dwelling unit (DU) in Destin, Florida is used in this study to calculate the costs of new roads, including sidewalks and bike paths, in Destin. The calculations prepared by Duncan Associates are used because the data required for this type of analysis requires the resources of an engineering company or large consulting firm. The formula used by Duncan Associates to calculate road (transportation) costs is shown as Equation (4).

\section{Transportation Costs $=$ EDUs $x$ NETCOST/EDU}

Where:

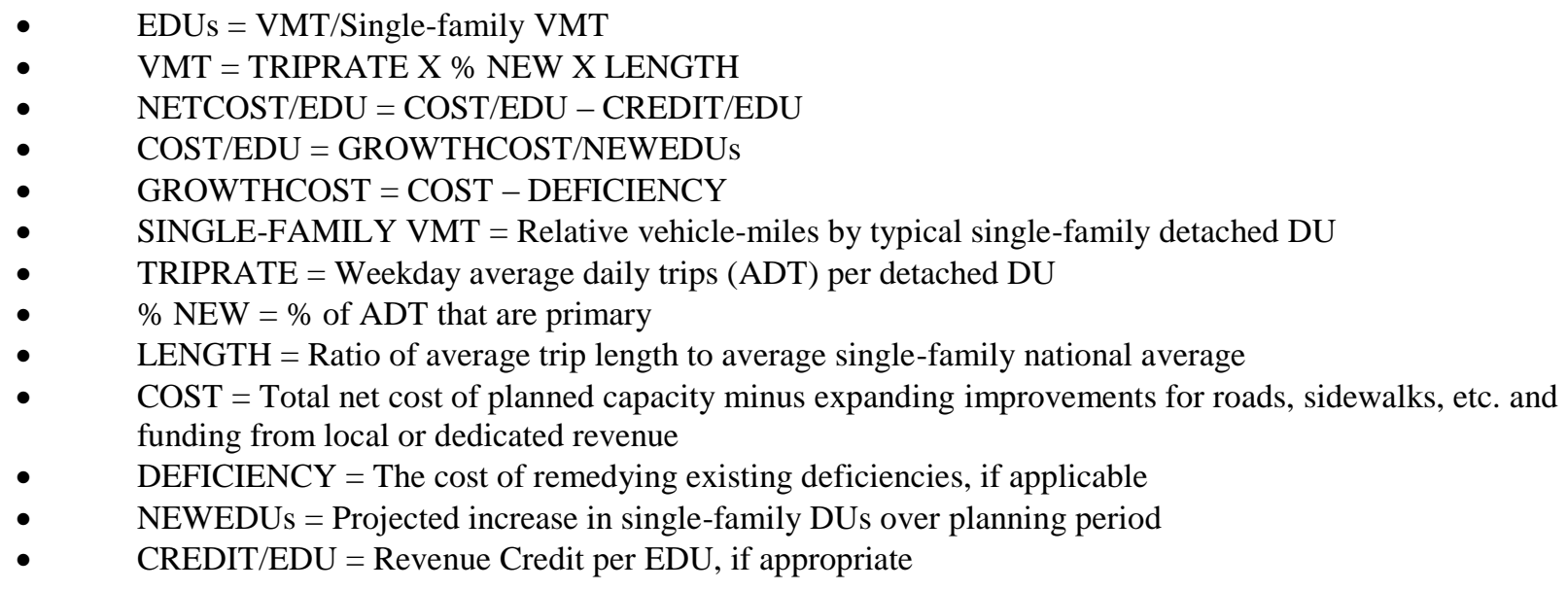

\section{RESULTS}

Impact fees are used in 41 of the 67 counties in Florida. Most of the Florida counties with impact fees are in the southern, central, and northeastern areas of the state. Table 2 provides the total impact fee for each county with impact fees, and also provides each county's impact fees for roads, drainage, parks, libraries, fire protection, police protection, government buildings, schools, and other impact fees, such fees for administering the impact fee system and correctional facilities. The total impact fees for a three bedroom, 2,000 sf home vary widely among the counties from the highest fees levied by Collier County $(\$ 24,428)$ and Manatee County $(\$ 15,529)$ to the lowest fees of Okaloosa County $(\$ 781)$ and Levy County $(\$ 1,249)$. The average impact fee for counties with impact fees and counties with municipalities that have impact fees is $\$ 7,340$ which is higher than the national average of $\$ 6,701$. The average impact fees for schools and roads, $\$ 3,864$ and $\$ 2,967$ respectively, are the highest average impact fees levied in Florida, with the average impact fee of $\$ 929$ for parks coming in a distant third. According to Duncan Associates (July, 2007) "Over the last four years impact fees have increased about 77 percent, while construction costs have increased about 19 percent. The increases were most pronounced in Florida, where school fees, which saw the largest increases, are becoming more common and are being aggressively increased."

\section{School Costs vs. Average Florida School Impact Fees}

The costs used are the actual costs experienced by Santa Rosa County when building the Bennett C. Russell Elementary School. The methodology used is from a study done by Henderson, Young Company (2007). 
Table 2

Single-Family Unit (3 BR, 2,000 sf on 10,000 sf Lot)

\begin{tabular}{|c|c|c|c|c|c|c|c|c|c|c|}
\hline County & Roads & Drainage & Parks & Library & Fire & Police & $\begin{array}{l}\text { Gov't } \\
\text { Bldg }\end{array}$ & Schools & Other & Total \\
\hline Alachua & $\$ 2,104$ & $\mathrm{n} / \mathrm{a}$ & $\$ 252$ & $\mathrm{n} / \mathrm{a}$ & $\$ 152$ & $\mathrm{n} / \mathrm{a}$ & $\mathrm{n} / \mathrm{a}$ & $\mathrm{n} / \mathrm{a}$ & $\mathrm{n} / \mathrm{a}$ & $\$ 2,508$ \\
\hline Brevard & 4,208 & $\mathrm{n} / \mathrm{a}$ & 558 & $\$ 64$ & 106 & $\$ 38$ & $\$ 250$ & $\$ 4,445$ & $\$ 232$ & 9,901 \\
\hline Broward & 457 & $\mathrm{n} / \mathrm{a}$ & 1,396 & $\mathrm{n} / \mathrm{a}$ & $\mathrm{n} / \mathrm{a}$ & $\mathrm{n} / \mathrm{a}$ & $\mathrm{n} / \mathrm{a}$ & 1,844 & $\mathrm{n} / \mathrm{a}$ & 3,697 \\
\hline Charlotte & 5,080 & $\mathrm{n} / \mathrm{a}$ & 1,660 & 160 & 400 & 300 & 780 & $\mathrm{n} / \mathrm{a}$ & $\mathrm{n} / \mathrm{a}$ & 8,380 \\
\hline Citrus & 4,853 & $\mathrm{n} / \mathrm{a}$ & 723 & 251 & 497 & 257 & 625 & 2,109 & $\mathrm{n} / \mathrm{a}$ & 9,315 \\
\hline Clay & $\mathrm{n} / \mathrm{a}$ & $\mathrm{n} / \mathrm{a}$ & $\mathrm{n} / \mathrm{a}$ & $\mathrm{n} / \mathrm{a}$ & $\mathrm{n} / \mathrm{a}$ & $\mathrm{n} / \mathrm{a}$ & $\mathrm{n} / \mathrm{a}$ & 7,034 & $\mathrm{n} / \mathrm{a}$ & 7,034 \\
\hline Collier & 8,884 & $\mathrm{n} / \mathrm{a}$ & 3,299 & 506 & 1,195 & 318 & 807 & 9,206 & 213 & 24,428 \\
\hline Dade & 1,275 & $\mathrm{n} / \mathrm{a}$ & 4,365 & $\mathrm{n} / \mathrm{a}$ & 441 & 255 & 413 & 2,448 & $\mathrm{n} / \mathrm{a}$ & 9,197 \\
\hline DeSoto & 2,534 & $\mathrm{n} / \mathrm{a}$ & 370 & 163 & 398 & 538 & 647 & 4,563 & $\mathrm{n} / \mathrm{a}$ & 9,213 \\
\hline Flagler & 3,900 & $\mathrm{n} / \mathrm{a}$ & 733 & $\mathrm{n} / \mathrm{a}$ & 185 & $\mathrm{n} / \mathrm{a}$ & $\mathrm{n} / \mathrm{a}$ & 3,600 & $\mathrm{n} / \mathrm{a}$ & 8,418 \\
\hline Gilchrist & 1,750 & $\mathrm{n} / \mathrm{a}$ & $\mathrm{n} / \mathrm{a}$ & $\mathrm{n} / \mathrm{a}$ & $\mathrm{n} / \mathrm{a}$ & $\mathrm{n} / \mathrm{a}$ & 1,000 & 750 & $\mathrm{n} / \mathrm{a}$ & 3,500 \\
\hline Glades & 3,363 & $\mathrm{n} / \mathrm{a}$ & 365 & $\mathrm{n} / \mathrm{a}$ & 93 & $\mathrm{n} / \mathrm{a}$ & $\mathrm{n} / \mathrm{a}$ & 4,322 & $\mathrm{n} / \mathrm{a}$ & 8,143 \\
\hline Hardee & 1,348 & $\mathrm{n} / \mathrm{a}$ & 292 & 146 & 193 & 152 & 349 & $\mathrm{n} / \mathrm{a}$ & 146 & 2,626 \\
\hline Hendry & 2,490 & $\mathrm{n} / \mathrm{a}$ & $\mathrm{n} / \mathrm{a}$ & $\mathrm{n} / \mathrm{a}$ & $\mathrm{n} / \mathrm{a}$ & $\mathrm{n} / \mathrm{a}$ & $\mathrm{n} / \mathrm{a}$ & 5,101 & $\mathrm{n} / \mathrm{a}$ & 7,591 \\
\hline Hernando & 3,627 & $\mathrm{n} / \mathrm{a}$ & 501 & 154 & 229 & 99 & 362 & 4,266 & $\mathrm{n} / \mathrm{a}$ & 9,238 \\
\hline Highlands & 1,649 & $\mathrm{n} / \mathrm{a}$ & 189 & 61 & 190 & 58 & $\mathrm{n} / \mathrm{a}$ & 2,901 & 171 & 5,219 \\
\hline Hillsboro. & 1,894 & $\mathrm{n} / \mathrm{a}$ & 468 & 538 & 137 & 304 & $\mathrm{n} / \mathrm{a}$ & 2,000 & $\mathrm{n} / \mathrm{a}$ & 5,341 \\
\hline Indian Riv. & 5,202 & $\mathrm{n} / \mathrm{a}$ & 1,463 & 483 & 278 & 244 & 206 & 1,756 & 245 & 9,877 \\
\hline Lake & 2,189 & $\mathrm{n} / \mathrm{a}$ & 411 & 242 & 258 & 138 & $\mathrm{n} / \mathrm{a}$ & 7,055 & $\mathrm{n} / \mathrm{a}$ & 10,293 \\
\hline Lee & 6,736 & $\mathrm{n} / \mathrm{a}$ & 1,155 & $\mathrm{n} / \mathrm{a}$ & 570 & 632 & $\mathrm{n} / \mathrm{a}$ & 4,309 & 857 & 14,259 \\
\hline levy & 1,046 & $\mathrm{n} / \mathrm{a}$ & 150 & $\mathrm{n} / \mathrm{a}$ & 53 & $\mathrm{n} / \mathrm{a}$ & $\mathrm{n} / \mathrm{a}$ & $\mathrm{n} / \mathrm{a}$ & $\mathrm{n} / \mathrm{a}$ & 1,249 \\
\hline Manatee & 7,013 & $\mathrm{n} / \mathrm{a}$ & 971 & $\mathrm{n} / \mathrm{a}$ & 582 & 839 & $\mathrm{n} / \mathrm{a}$ & 6,124 & $\mathrm{n} / \mathrm{a}$ & 15,529 \\
\hline Marion & 3,047 & $\mathrm{n} / \mathrm{a}$ & $\mathrm{n} / \mathrm{a}$ & $\mathrm{n} / \mathrm{a}$ & 212 & $\mathrm{n} / \mathrm{a}$ & $\mathrm{n} / \mathrm{a}$ & $\mathrm{n} / \mathrm{a}$ & $\mathrm{n} / \mathrm{a}$ & 3,259 \\
\hline Martin & 2,688 & $\mathrm{n} / \mathrm{a}$ & 2,255 & 438 & 333 & 428 & 550 & 4,374 & $\mathrm{n} / \mathrm{a}$ & 11,066 \\
\hline Monroe & 430 & $\mathrm{n} / \mathrm{a}$ & 340 & 242 & 105 & 150 & $\mathrm{n} / \mathrm{a}$ & $\mathrm{n} / \mathrm{a}$ & 64 & 1,331 \\
\hline Nassau & 984 & $\mathrm{n} / \mathrm{a}$ & 431 & $\mathrm{n} / \mathrm{a}$ & 110 & 136 & 210 & 3,726 & $\mathrm{n} / \mathrm{a}$ & 5,597 \\
\hline Okaloosa & 577 & $\mathrm{n} / \mathrm{a}$ & 113 & 76 & $\mathrm{n} / \mathrm{a}$ & 15 & $\mathrm{n} / \mathrm{a}$ & $\mathrm{n} / \mathrm{a}$ & $\mathrm{n} / \mathrm{a}$ & 781 \\
\hline Orange & 2,236 & $\mathrm{n} / \mathrm{a}$ & 724 & $\mathrm{n} / \mathrm{a}$ & 229 & 238 & $\mathrm{n} / \mathrm{a}$ & 3,807 & $\mathrm{n} / \mathrm{a}$ & 7,234 \\
\hline Osceola & 4,126 & $\mathrm{n} / \mathrm{a}$ & 679 & $\mathrm{n} / \mathrm{a}$ & 159 & $\mathrm{n} / \mathrm{a}$ & $\mathrm{n} / \mathrm{a}$ & 6,567 & $\mathrm{n} / \mathrm{a}$ & 11,531 \\
\hline Palm Beach & 4,002 & $\mathrm{n} / \mathrm{a}$ & 2,340 & 136 & 355 & 300 & 113 & 1,931 & $\mathrm{n} / \mathrm{a}$ & 9,177 \\
\hline Pasco & 5,176 & $\mathrm{n} / \mathrm{a}$ & 627 & 97 & 420 & $\mathrm{n} / \mathrm{a}$ & $\mathrm{n} / \mathrm{a}$ & 1,674 & 241 & 8,235 \\
\hline Pinellas & 1,420 & $\mathrm{n} / \mathrm{a}$ & $\mathrm{n} / \mathrm{a}$ & $\mathrm{n} / \mathrm{a}$ & $\mathrm{n} / \mathrm{a}$ & $\mathrm{n} / \mathrm{a}$ & $\mathrm{n} / \mathrm{a}$ & $\mathrm{n} / \mathrm{a}$ & $\mathrm{n} / \mathrm{a}$ & 1,420 \\
\hline Polk & 5,485 & $\mathrm{n} / \mathrm{a}$ & 617 & 145 & 202 & 175 & $\mathrm{n} / \mathrm{a}$ & 4,082 & 72 & 10,778 \\
\hline Putnam & 1,577 & $\mathrm{n} / \mathrm{a}$ & 187 & $\mathrm{n} / \mathrm{a}$ & 159 & $\mathrm{n} / \mathrm{a}$ & $\mathrm{n} / \mathrm{a}$ & 2,217 & $\mathrm{n} / \mathrm{a}$ & 4,140 \\
\hline Santa Rosa & 1,265 & $\mathrm{n} / \mathrm{a}$ & $\mathrm{n} / \mathrm{a}$ & $\mathrm{n} / \mathrm{a}$ & $\mathrm{n} / \mathrm{a}$ & $\mathrm{n} / \mathrm{a}$ & $\mathrm{n} / \mathrm{a}$ & $\mathrm{n} / \mathrm{a}$ & $\mathrm{n} / \mathrm{a}$ & 1,265 \\
\hline St Johns & 3,096 & $\mathrm{n} / \mathrm{a}$ & 629 & $\mathrm{n} / \mathrm{a}$ & 418 & 157 & 315 & 2,290 & $\mathrm{n} / \mathrm{a}$ & 6,905 \\
\hline St Lucie & 1,628 & $\mathrm{n} / \mathrm{a}$ & 431 & 125 & 97 & 164 & 329 & 2,536 & $\mathrm{n} / \mathrm{a}$ & 5,310 \\
\hline Sarasota & 4,484 & $\mathrm{n} / \mathrm{a}$ & 1,364 & 291 & 357 & 150 & 207 & 474 & 328 & 7,655 \\
\hline Seminole & 1,110 & $\mathrm{n} / \mathrm{a}$ & 684 & 73 & 348 & 262 & 400 & 639 & $\mathrm{n} / \mathrm{a}$ & 3,516 \\
\hline Sumter & 1,402 & $\mathrm{n} / \mathrm{a}$ & $\mathrm{n} / \mathrm{a}$ & $\mathrm{n} / \mathrm{a}$ & 397 & $\mathrm{n} / \mathrm{a}$ & $\mathrm{n} / \mathrm{a}$ & $\mathrm{n} / \mathrm{a}$ & $\mathrm{n} / \mathrm{a}$ & 1,799 \\
\hline Volusia & 1,438 & $\$ 31$ & 828 & $\mathrm{n} / \mathrm{a}$ & 171 & 108 & 256 & 6,066 & $\mathrm{n} / \mathrm{a}$ & 8,898 \\
\hline State Aver. & 2,937 & 31 & 929 & 220 & 295 & 248 & 434 & 3,684 & 257 & 7,340 \\
\hline
\end{tabular}

Source: Duncan Associates (August, 2007)

Step 1. Calculate the total cost of the facilities per student Using Equation 1.

Construction costs

Furniture, equipment, etc. costs

$\mathrm{PV}$ of expected interest on loan

Total Cost
$\$ 19,594,637$

$1,449,614$

$\underline{14,157,918}$

$\$ 35,202,169$ 
Cost per Student $=\$ 35,202,169 / 900=\$ 39,114$

Step 2. Calculate the cost of the facilities per dwelling unit using Equation 2.

Cost per Dwelling Unit $(\mathrm{DU})=$ Cost per Student $\mathrm{x}$ Students per $\mathrm{DU}$

Cost per DU $=\$ 39,114 \times 0.42=\$ 16,428$

Step 3. Calculate the estimated yearly costs for new schools using Equation 3.

Estimated yearly Costs for New Schools = Cost per DU x Number of New DUs per year

Estimated Yearly Costs for New Schools $=\$ 16,428 \times 1,492=\$ 24,510,576$

Step 4. Compare the estimated yearly costs for new facilities $(\$ 24,510,576)$ to the estimated total school impact fees for 1,492 new DUs calculated as follows:

Total estimated yearly impact fees $=1,492$ (new DUs) $x \$ 3,684$ (av. Florida school impact fee) $=$ $\$ 5,496,528$

The estimated yearly costs for new schools $(\$ 24,510,576)$ clearly exceed the estimated school impact fees revenue.

\section{Transportation Costs vs. Transportation Impact Fees in Destin, Florida}

Unlike the analysis of school costs in Santa Rosa County vs. the average school impact fee in Florida completed above where the required data was available primarily through the Santa Rosa School Board, obtaining the data for the transportation costs in Destin would require extensive research and analysis, probably by an engineering firm or large consulting firm. In addition, whereas the calculations required for school costs are fairly straightforward, the calculations for transportation costs are much more complex and time consuming. Therefore, the methodology and results of the study conducted by Duncan Associates (July, 2007) are used to determine the costs of improving the roads, sidewalks and bike paths required by the planned growth in Destin.

The Duncan Associates study estimates that 3,513 single-family equivalent dwelling units (EDUs) in Destin will be added during the period 2006 - 2030. The study also estimates the total cost for improvements to the transportation infrastructure to be $\$ 16,518,861$. Therefore, the cost per EDU is equal to the total estimated cost of the transportation infrastructure improvements $(\$ 16,518,861)$ divided by the total number of planned EDUs $(3,513)$, which is equal to $\$ 4,702$. The transportation cost per EDU in Destin is $\$ 4,702$ which is much higher than Destin's current transportation impact fee of $\$ 471$ and higher than the transportation impact fee recommended by the Duncan Associates study of $\$ 4,377$. The calculated cost per EDU is also higher than the Florida average roads impact fee which is $\$ 2,937$.

The estimated future costs of the transportation infrastructure in Destin clearly is higher than the estimated transportation impact fee revenues from Destin's current transportation impact fee, the new transportation impact fee estimated by the Duncan Associates study, and the average Florida roads impact fee.

\section{CONCLUSION}

Impact fees are used by counties, municipalities, school districts, and special districts to pay for the costs of additional infrastructure required as a result of new development. The highest cost impact fees are for schools and roads, however, impact fees in lower dollar amounts are also used for fire and police protection, government 
buildings, emergency medical services, correctional facilities, parks, libraries, and drainage. Impact fees have a wide appeal to geographical areas experiencing growth and 34 states in the U.S. currently have impact fees in force. Since attempting to determine if impact fees pay for the infrastructure costs required for the growth in single-family homes in all 34 states was beyond the capability of this study, Florida was used as a proxy for all 34 states because 41 out of 67 counties in Florida have impact fees, and Florida is one of the fastest growing states in the U.S. The analysis of cost vs. impact fees was limited to school impact fees and road impact fees since the dollar value of all other impact fees pales in comparison to the impact fees for schools and roads. The results indicate that the costs of the infrastructure for the roads and schools required by the estimated growth were significantly higher than the impact fees charged. There are two primary reasons for this finding. First, because of the decisions handed down from many court cases on impact fees in Florida, impact fees can only be used to supplement current funding for growth infrastructure. This means that counties and school districts that have a budget line item for capital development, or have a sales tax in force which must be used for roads or schools, must deduct these funding sources from the total costs of the infrastructure when calculating impact fees. The second, and probably the most important reason why estimated infrastructure costs are greater than impact fees is because county commissioners and school board members are overly influenced to keep impact fees low by developers and other real estate interests.

\section{REFERENCES}

1. Burge, Gregory, and Keith Ihlanfeldt. 2006. The Effects of Impact Fees on Multi-Family Housing Construction. Journal of Regional Science 46, No. 1, 5-23.

2. Duncan/Associates. July 2007. Impact Fee Study Destin, Florida.

3. Duncan/Associates. August 2007. National Impact Fee Survey: 2007.

4. Henderson Young \& Company. 2007. Impact Fees for Educational Facilities in Lake County, Florida.

5. Ihlanfeldt, Keith and Timothy Schaughnessy. 2004. An Empherical Investigation of the Effects of Impact Fees on Housing and Land Markets. Regional Science and Urban Economics 34, 639-661.

6. Moon, Gi Jeong. 2006. Local Choices for Development Impact Fees. Urban Affairs Review 41, No. 3 , 338-357.

7. Yinger, John. 1998. The incidence of Development Fees and Special Assessments. National Tax Journal 51, No. 1, 23-41. 
NOTES 